\title{
Managing Land Use Transformation and Land Surface Temperature Change in Anyigba Town, Kogi State, Nigeria
}

\author{
Ifatimehin Olarewaju Oluseyi (Corresponding author) \\ Department of Geography and Planning, Kogi State University, P.M.B. 1008, Anyigba, Nigeria \\ Tel: 234-805-917-8949Ｅ-mail: lanreifa@yahoo.com \\ Musa Salihu Danlami (PhD) \\ Department of Geography and Planning, Kogi State University, P.M.B. 1008, Anyigba, Nigeria \\ Tel: 234-803-595-5767_E-mail: musasd767@yahoo.com \\ Adeyemi John Olusegun \\ Department of Geography and Planning, Kogi State University, P.M.B. 1008, Anyigba, Nigeria \\ Tel: 234-803-643-8036_E-mail: silvershegz@yahoo.com
}

Received: June 2, 2010 Accepted: June 25, 2010 doi:10.5539/jgg.v3n1p77

\begin{abstract}
The uncontrolled urban growth in cities comes with unattending alteration in the urban environmental system. This alteration as land use types change is most responsible for some of the problems witnessed in urban town such as the variation in land surface temperatures over time. This study used Remote sensing and GIS techniques to identify, mark and measure the extent of the various land uses from the Landsat TM image of 1995 and Landsat ETM+ image of 2006. The study revealed that the spatial and temporal changes in the land uses have greatly influenced the increase in the land surface temperature of each of the identified land uses. As vacant land and built-up area increased by $3.28 \mathrm{ha} / \mathrm{yr}$ and $78.34 \mathrm{ha} / \mathrm{yr}$ so did their land surface temperature increased by $0.083^{\circ} \mathrm{C} / \mathrm{yr}$. While vegetation and water and wetland vegetation decreased, their respective land surface temperature increased by $0.075^{\circ} \mathrm{C} / \mathrm{yr}$ and $0.083^{\circ} \mathrm{C} / \mathrm{yr}$. This increase in land surface temperature of the study area within the period of study suggest that the rise in temperature of the various land uses may encourage environmental problems associated with local climate change as heat waves and mosquito infestations which can cause human discomfort as its been witnessed today in Anyigba. Proper checks on the development and conversion of land uses, urban forestry and adequate planning if employed may help in managing this occurence from agravating other environmental problems associated with land uses change and climate change.
\end{abstract}

Keywords: Anyigba, Environment, Images, Land sureface temperature, Land use change, Urban growth

\section{Introduction}

The rapid growth in both population and economic output per capita, and the consequent changes in land use pattern have implications on the natural environment (Cohen, 2004; Tang et al., 2005; Ifatimehin and Ufuah, 2006b; Ifatimehin and Musa, 2008; Ifatimehin, Musa and Adeyemi, 2009). This phenomenon of change in land use is one of the most prominent forces altering our local and regional environments. The consequences on the environment include degradation, depreciation, depletion and deterioration of resources. These represent some of the common environmental problems of the 21st century. Sackey (2008) and (Weng, 2001) posited that uncontrolled land expansion and its transformation lead to loss of natural vegetation and open space and a general decline in the extent, efficient and effective provision of ecosystem services to the environment undergoing such change.

The clouds, land use, sea and land surface temperature, and exchanges of energy and moisture are features that vary very rapidly in time and space and are considered to adequately explain the micro, meso and global climate change. Land surface temperatures (LSTs) are most important in global climate change studies: in estimating radiation budget, heat balance and as control for climate models (Wubet, 2003), and are strongly influenced by 
the ability of the different surfaces to emit radiation differently. However, the surface emissivity of land use/cover differs; it is relatively uniform for densely vegetated surfaces and highly variable for heterogeneous surfaces, such as soils and other impervious surfaces (Ifatimehin, 2007 and Weng, 2001)

Urban growth and its expansion do not always come with its expected economic growth, the scenerio results from poor urban planning and uncontrolled land use, lack of financial resources and inadequate investment in environmental management (UNCHS, 1996). This has also led to serious environmental and ecological problems (Zhao et al, 2006) and altered the local climate both in urban and surroundings areas (Kalnay and Cai (2003)

Anyigba town is one of the fastest growing university towns in Nigeria today as commerce is fast evolving and shaping the town's economy (Ifatimehin and Ufuah, 2006a) and the landscape. This activity has initiated various levels of land use transformation: agricultural land are lost on a daily basis to construction of houses and business centres (Ifatimehin, et al., 2009). The pressure exerted by the growing population on the land and other resources and the continual changing of the various land uses is noticeable in this town.

The objectives of this paper are to:

i. Analyse past and present land use pattern in Anyigba,

ii. Relates the changing land use to the changing land surface temperature

iii. Justify the consequences of the changes on Anyigba Environment.

\section{Study area description}

Anyigba, the study area is located on latitude $7^{\circ} 15^{\prime}-7^{\circ} 29^{\prime} \mathrm{N}$ and longitude $7^{\circ} 11^{\prime}-7^{\circ} 32^{\prime} \mathrm{E}$ and with an average altitude of 420 meters above sea level (Figure 1). The population is estimated to be 71,327 persons based on 1991 growth rate of $3.25 \%$. There are no significant differences with regard to socioeconomic status, and educational level in the study area (Ifatimehin and Ufuah, 2006a). The study area falls within the tropical wet and dry (Aw) climatic region and the guinea savanna, with mean annual temperature of $25^{\circ} \mathrm{C}$ and rainfall $1600 \mathrm{~mm}$. It is situated on sedimentary formation of the Anambra basin and dominated by lateritic soil type with patches of hydromorphic and rich loamy soils. The presence of a university is rapidly initiating and transforming the land use type and economy from agrarian to a commerce driven economy.

\section{Materials and methods}

Landsat TM image and Landsat ETM+ of $8^{\text {th }}$ September 1995 and $12^{\text {th }}$ September 2006 respectively were analysed using GIS techniques provided by Idrisi 32 and ILWIS Academia 3.4 softwares. Training sample sets were generated using the Global Positioning System (GPS) during ground truthing. These imageries were appropriately classified using the Maximum Likelihood approach and information on land use, hydrological and other environmental parameters were drawn (Figure 2a). Statistical analysis were employed to define the spatial and temporal variation in the different land uses over the period of the study.

The radiometrically corrected LandSat TM thermal infrared data (band 6) was used for this purpose. The following methods were adopted:

i. Digital Number $(\mathrm{DN})$ conversion to radiance:

$$
L_{k}=\frac{\left(L_{\min }-L_{\max }\right) \times D N}{255}+\text { offset }
$$

ii. Conversion from radiance to reflectance (Surface albedo):

$$
r_{0}=\frac{\left(r p-r p_{\min }\right)}{t}
$$

Where $\mathrm{t}$ is transmisivity $=0.954204-0.08137 T_{o}$ where $T_{o}$ is the near surface temperature. While rp is the broadband reflectance $=$

$$
\mathrm{rp}=\frac{\sum \operatorname{ESUN} \times \mathrm{rp}(\lambda)}{\sum \operatorname{ESUN}_{\lambda}}
$$

Where ESUN=mean solar exo atmospheric irradiance 
$\operatorname{rp}\left(\lambda_{1}\right)$ is the planetary reflectance $=$

$$
\operatorname{rp}(\lambda)=\frac{\pi \times L_{\lambda} \times d^{2}}{\sum \operatorname{ESUN}_{\lambda} \times \operatorname{Cos} Q}
$$

$\mathrm{L}_{\lambda}=$ spectral radiance at the sensor apecture

$\mathrm{d}=$ earth sun distance

$\operatorname{Cos} \mathrm{Q}=$ solar Zenith angle

$\mathrm{t}=$ one way atmospheric transmittance

iii. The NDVI image was computed for 2001 from the band 3 and band 4 reflectance data using the formula below:

$$
N D V l=\frac{r 4-r 3}{r 4+r 3}
$$

iv. Emissivity, $\varepsilon 0=(1.094+0.047 \mathrm{x} \ln (\mathrm{NDVI}))$

v. $T_{a}=16.7345+0.916527 T_{o}, T_{a}$ is the mean atmospheric temperature

vi. $\quad$ Effective satellite temperature $\mathrm{T}_{\mathrm{s}}$ :

$$
T_{\mathrm{s}}=\frac{\mathrm{K}_{2}}{\ln \left(\mathrm{K}_{1} / L \lambda\right)+1}
$$

vii. The Qin et al's mono-wnidow algorithm developed in 2001 was use to obtain the land surface temperature $(T)$ :

$$
\begin{gathered}
T=\frac{1}{\mathrm{C}}\left[\alpha(1-\mathrm{C}-\mathrm{D})+(\mathrm{b}(1-\mathrm{C}-\mathrm{D})+\mathrm{C}+\mathrm{D}) T_{s}-D T_{\mathrm{a}}\right] \\
\mathrm{C}=\mathrm{t} \varepsilon \\
D=(1-t)[1+t(1-\varepsilon)]
\end{gathered}
$$

Where $\lambda=$ wavelength of emitted radiance $=11.5 \mu \mathrm{m}$ (Markam and Barker, 1985), $\alpha=h c / k\left(1.438 \times 10^{-2} \mathrm{mK}\right)$, $\mathrm{k}=$ Stefan Boltzmann's constant $\left(1.38 \times 10^{-23} \mathrm{JK}^{-1}\right), \mathrm{h}=$ Planck's constant $\left(6.26 \times 10^{-34} \mathrm{Js}\right)$, and $\mathrm{c}=$ velocity of light $\left(2.998 \times 10^{8} \mathrm{~s}^{-1}\right), \mathrm{a}=-67.345$ and 0.4658

Figure 3 shows the flowchart for the computation of surface temperature $\left(T^{5}\right)$

The derived LST Maps were imported to ILWIS software and overlaid on the classified landuse maps. The Map Calculation Operator of ILWIS Software was used to generate the landuse/LST Maps for the period of study.

\section{Result analysis and discussion}

The rapid land use changes in Anyigba is largely due to its new status as a university town. In the last few years, the town and its surroundings have undergone radical changes in land use types and in consumption and utilization of resources.

\subsection{Land use types in Anyigba}

The total areal coverage of Anyigba measured 4206 hectares in this study. Five categories of land use types were identified (Table 1).

The 1995 and 2006 classified land use maps (Figure 4) revealed that vacant land, built-up area and cultivated land had increased tremendiously by $39.34 \mathrm{ha}, 940.07 \mathrm{ha}$ and 278.75 ha respectively. While on the other hand, vegetation and stream had lost 1023.85 ha and 234.31 ha respectively. The highest increase recorded by built-up area is evident in the number of buildings being developed in response to the influx of people to the opportunities offered by the presence of the university. 
However, the drastic decrease witnessed in vegetation and water and wetland vegetation can be associated to the expansion of built-up area, vacant and cultivated land uses. The need for houses, open space and food are most responsible for the decrease as corroborated by the findings of these authors Ifatimehin and Musa (2008); Fasal (2000) and Nicolson (1987)

\subsection{Land surface temperatures of Anyigba}

The land surface temepratures of the respective land uses identified as shown in the LST Maps (Figure 5), it is clear in both years (Table 2), vacant land exhibits the highest surface temperature $\left(27.9-29.0^{\circ} \mathrm{C}\right.$ in 1995 and $28.9-30.0^{\circ} \mathrm{C}$ in 2006), followed by built-up area $\left(26.7-27.8{ }^{\circ} \mathrm{C}\right.$ in 1995 and $27.7-28.8{ }^{\circ} \mathrm{C}$ in 2006). This implies that urban development does bring up surface temperatures by replacing natural vegetation with non-evaporating, non-transpiring surfaces such as bare land (soils), metal, tar, cemented buildings and concrete. The dry nature of these non-evapotranspirative materials in the urban environment is responsible for variation as the vegetation (24.3-25.4 ${ }^{\circ} \mathrm{C}$ in 1995 and $25.2-26.3{ }^{\circ} \mathrm{C}$ in 2006), cultivated land (25.5-26.6 ${ }^{\circ} \mathrm{Cin} 1995$ and $26.4-27.6{ }^{\circ} \mathrm{C}$ in 2006$)$ and water bodies $\left(23.0-24.1^{\circ} \mathrm{C}\right.$ in 1995 and $24.0-25.1{ }^{\circ} \mathrm{C}$ in 2006) are evaporative and transpirative. Cultivated land surface temperature is higher than that of vegetation and water body because part of the crop field soils are exposed and not covered in its entirety.

The changes in land surface temperatures of the various land uses between 1995 and 2006 shows that there was $1^{\circ} \mathrm{C}$ difference and increase in surface temperature of vacant land, built-up area and stream, while cultivated land and vegetation also had increase of $0.95^{\circ} \mathrm{C}$ and $0.9^{\circ} \mathrm{C}$ respectively.

\subsection{The impact of land use change on land surface temperatures}

The impact of land use on land surface temperature during this study shows that spatially there are relationships in changes as reflected in the characteristics of the individual land uses. The rate of change in vacant land of 3.28 $\mathrm{ha} / \mathrm{yr}$ is accompanied also with increase land surface temperature $\left(0.083^{\circ} \mathrm{C} / \mathrm{yr}\right)$ annually, so it is with built up area $\left(78.34 \mathrm{ha} / \mathrm{yr}-0.083^{\circ} \mathrm{C} / \mathrm{yr}\right)$ and cultivated land $\left(23.23 \mathrm{ha} / \mathrm{yr}-0.079{ }^{\circ} \mathrm{C} / \mathrm{yr}\right)$. While vegetation and stream/wetland vegetation witnessed decrease in their land area annually but with an increase in their surface temperature of $0.075{ }^{\circ} \mathrm{C} / \mathrm{yr}$ and $0.083{ }^{\circ} \mathrm{C} / \mathrm{yr}$. The environmental function of vegetation in shading surfaces, evaporation of water, altering windspeeds and modifying the storage and exchange of heat between urban surfaces and as it influences local climate is impeded by its decrease as a result of urban expansion. Therefore, the overall cooling effect to the environment is reduced and thereby allow increase in surface temperature.

\section{Policy implications}

Undoubtedly, with the rate of expansion of built up area at $78.34 \mathrm{ha} / \mathrm{yr}$, and decrease of vegetation at $85.32 \mathrm{ha} / \mathrm{yr}$, Anyigba may face imminent environmental crises in years to come as heat waves will be on rise. This suggest that human discomfort like climate and heat related ailments and vector (mosquitoes) causing diseases such as malaria will also increases. In this era of climate change and its attending consequences, calls for urgent steps in addressing these problems to avert their negative implications on the environment have become pertinent.

In order to ensure activities and measures that will enhance an environment which will be less deteriorating, depleting and degrading, human activities need to be regulated. One important way is by incorporating environmental policies into the master plan. This will facilitate comprehensive land use planning for residential and commercial layouts, utilities [drainages, potential waste dumps], and even cultivated land. Aside this, environmental policies (that make the environment more habitable and friendly) like regular sanitation exercises and tree planting should be strengthened and enforced among residents.

Another vital contemporary measure that should be encouraged by both the government and residents is the concept of "Urban Forestry". This aims at afforesting the urban environment, which is being seriously threatened in Anyigba. The entire populace should also be well enlightened about the importance of good waste management, pollution control and protection of the environment at large. Above all, the importance of ecosystem services provided by vegetation and water should be emphasised as their preservation and conservation will enhance sustainable resource utilization.

\section{Conclusion}

Drastic landuse changes have taken place in Anyigba within the period under consideration with Built up area particularly recording the highest increase at the detriment of vegetation and water/wetland vegetation. The surface temperature of the area also recorded slight increases across the various land uses. Vegetation plays a vital role in making our environment comforting. Unabated loss of vegetation will therefore result in serious environmental consequences as is already being experienced in the heat flux (increases). Deliberate efforts must therefore be made to reduce the rate of vegetation losses through effective planning and development control. 


\section{References}

Cohen, J. E. (2004). How Many People Can the Earth Support? W.W. Norton \& Co.New York.

Fasal, S. (2000). Urban Expansion and Loss of Agricultural Land-A GIS based Study of Saharanpur City, India. Environment and Urbanization. 12(2): 133-149 doi:10.1177/095624780001200211, http://dx.doi.org/10.1177/095624780001200211

Fohrer, N., Haverkamp, S., Eckhardt, K., \& Frede, H. G. (2001). Hydrologic Response to Land Use Changes on the Watershed Scale. Hydrology. Oceans and Atmosphere, 26(7-8), 577-582.

Gove, N., Edwards, R. T. \& Conquest, L. L. (2001). Effects of Scale on Land Use and Water Quality Relationships. Journal of American Water Resource Association, 37(6), 1721-1734. doi:10.1111/j.1752-1688.2001.tb03672.x, http://dx.doi.org/10.1111/j.1752-1688.2001.tb03672.x

Ifatimehin, O. O. (2007). An Assessment of Urban Heat Island of Lokoja Town and Surroundings Using Landsat ETM Data. FUTY Journal of the Environment, 2(1), 100-108.

Ifatimehin, O. O. \& Musa, S. D. (2008). Application of Geoinformatic Technology in Evaluating Urban Agriculture and Urban Poverty in Lokoja. Nigerian Journal of Geography and the Environment, 1(1), 21-31.

Ifatimehin, O. O., Musa, S. D. \& Adeyemi, J. O. (2009). An Analysis of the Changing Land use and its Impact of the Environment of Anyigba. Journal of Sustainable Development in Africa. 10(4), 357-364

Ifatimehin, O. O. \& Ufuah, M. E. (2006a). The Effect of a Spatial Structure on Rural Economy: A Case of Kogi State University on Anyigba and its Environ. Confluence Journal of Environmental Studies, 1(2), 61-70.

Ifatimehin, O. O. \& Ufuah, M. E. (2006b). An Analysis of Urban Expansion and Lost of Vegetation Cover in Lokoja Using GIS Techniques. Zaria Geographer: Journal of Environmental Studies and Human Development. 17(1): 28-36.

Kalnay, E \& Cai, M. (2003). Impact of Urbanization and Land Use change on Climate. Nature, 423, 528-531. doi:10.1038/nature01675, http://dx.doi.org/10.1038/nature01675

Kombe, W. J. \& Kreibich, V. (2000). Reconciling Informal and Formal Land Management: An Agenda for Improving Tenure security and Urban Governance in Poor Countries. Habitat International, 24(2), 231-240. doi:10.1016/S0197-3975(99)00041-7, http://dx.doi.org/10.1016/S0197-3975(99)00041-7

Mather, P. M. (1999). Computer Processing of Remotely Sensed Imageries-An Introduction. John Wiley and Sons, Toronto

Nicolson, L. D. (1987). The Greening of the Cities. Routledge and Kegan Paul, London doi:10.4324/9780203392614, http://dx.doi.org/10.4324/9780203392614

Qin, Z., Karnieli, A \& Berliner, P. (2001). A Mono-Window Algorithm for Retrieving Land Surface Temperature from Landsat TM Data and its Application to the Isreal-Egypt border region, International Journal of remote Sensing, 22(18), 3719-3746. doi:10.1080/01431160010006971, http://dx.doi.org/10.1080/01431160010006971

Rosa, E. A., York, R. \& Dietz, T. (2004). Tracking the Antropogenic Drivers of Ecological Impacts. Ambio: A Journal of the Human Environment, 33(8), 509-512.

Sackey, A. N. A. (2008). Environmental Impacts of Rapid Urbanization of Ethiopia's Cities In M.P. Van Dijk and J. Fransen (eds) Managing Ethiopian Cities in an Era of Rapid Urbanization. Eburon Delft. Pp. 119-131

Tang, Z., Engel, B. A., Pijanowski, B. C., \& Lim, K. J. (2005). Forecasting Land Use Change and its Environmental Impact at a Watershed Scale. Journal of Environmental Management, 76, 35-45. doi:10.1016/j.jenvman.2005.01.006, http://dx.doi.org/10.1016/j.jenvman.2005.01.006

UNCHS (1996). An Urbanizing World. World Global Report on Human Settlements. Oxford University Press, New York.

Weng, Q. (2001). A Remote Sensing-GIS Evaluation of Urban Expansion and Its Impact on Surface Temperature in the Zhujiang Delta, China, International J. Remote sensing, 22(10), 1999-2014.

Wubet, M. T. (2003). Estimation of Absolute Surface Temperature by Satellite Remote Sensing, Unpublished M.Sc Thesis, International Institute for Geoinformation Science and Earth Observation, Netherlands

Zhau, S, Da, L, Tang, Z, Fang, H, Song, K \& Fang, J. (2006). Ecological Consequences of Rapid Urban Expansion: Shanghai, China Frontiers in Ecological Environ; The Ecological Society of America, 4(7), 341-346 
Table 1. Anyigba Under Different Land Uses, 1995 and 2006

\begin{tabular}{|c|c|c|c|c|c|}
\hline \multirow{2}{*}{ Land use type } & \multicolumn{2}{|c|}{1995} & \multicolumn{2}{c|}{2006} & $\begin{array}{c}\text { Change in Land uses between } \\
1995 \text { to 2006 (ha) }\end{array}$ \\
\cline { 2 - 5 } & Area (ha) & $\%$ & Area (ha) & $\%$ & 39.34 \\
\hline Vacant Land & 176 & 4.19 & 215.34 & 5.12 & 940.07 \\
\hline Built-up Area & 315 & 7.49 & 1255.07 & 29.84 & 278.75 \\
\hline Cultivated Land & 2056 & 48.88 & 2334.75 & 55.51 & -1023.85 \\
\hline Vegetation & 1325 & 31.50 & 301.15 & 7.16 & -234.31 \\
\hline Water \& wetland vegetation & 334 & 7.94 & 99.69 & 2.37 & 100 \\
\hline Total & 4206 & 100 & 4206 & & \\
\hline
\end{tabular}

Source: Laboratory and Field Analysis, 2008

Table 2. Land uses types and their respective Land Surface Temperatures (LSTs)

\begin{tabular}{|c|c|c|c|c|c|}
\hline & VacantLand & Built-up Area & $\begin{array}{c}\text { Cultivated } \\
\text { Land }\end{array}$ & Vegetation & $\begin{array}{c}\text { Stream(Wetland } \\
\text { Vegetation) }\end{array}$ \\
\hline $\begin{array}{c}\text { Min \& Max LST } \\
(1995)\end{array}$ & $27.9-29.0^{\circ} \mathrm{C}$ & $26.7-27.8{ }^{\circ} \mathrm{C}$ & $25.5-26.6^{\circ} \mathrm{C}$ & $24.3-25.4{ }^{\circ} \mathrm{C}$ & $23.00-24.1^{\circ} \mathrm{C}$ \\
\hline $\begin{array}{c}\text { Min \& Max LST } \\
(2006)\end{array}$ & $28.9-30.0^{\circ} \mathrm{C}$ & $27.7-28.8^{\circ} \mathrm{C}$ & $26.4-27.6{ }^{\circ} \mathrm{C}$ & $25.2-26.3{ }^{\circ} \mathrm{C}$ & $24.00-25.1^{\circ} \mathrm{C}$ \\
\hline Change in LST & $+1{ }^{\circ} \mathrm{C}$ & $+1{ }^{\circ} \mathrm{C}$ & $+0.95{ }^{\circ} \mathrm{C}$ & $+0.9{ }^{\circ} \mathrm{C}$ & $+1{ }^{\circ} \mathrm{C}$ \\
\hline
\end{tabular}

Table 3. Rate of Change of land use and Land Surface Temperature in Anyigba between 1995 and 2006.

\begin{tabular}{|l|l|l|l|l|l|}
\hline & Vacant Land & Built-up Area & $\begin{array}{l}\text { Cultivated } \\
\text { Land }\end{array}$ & Vegetation & $\begin{array}{l}\text { Stream(Wetland } \\
\text { Vegetation) }\end{array}$ \\
\hline $\begin{array}{l}\text { Rate of LST Change in } 12 \\
\left.\text { Years ( }{ }^{\circ} \mathrm{C} / \mathrm{yr}\right)\end{array}$ & +0.083 & +0.083 & +0.079 & +0.075 & +0.083 \\
\hline $\begin{array}{l}\text { Rate of Land Use change in } \\
12 \text { years (ha/yr) }\end{array}$ & +3.28 & +78.34 & +23.23 & -85.32 & -19.53 \\
\hline
\end{tabular}




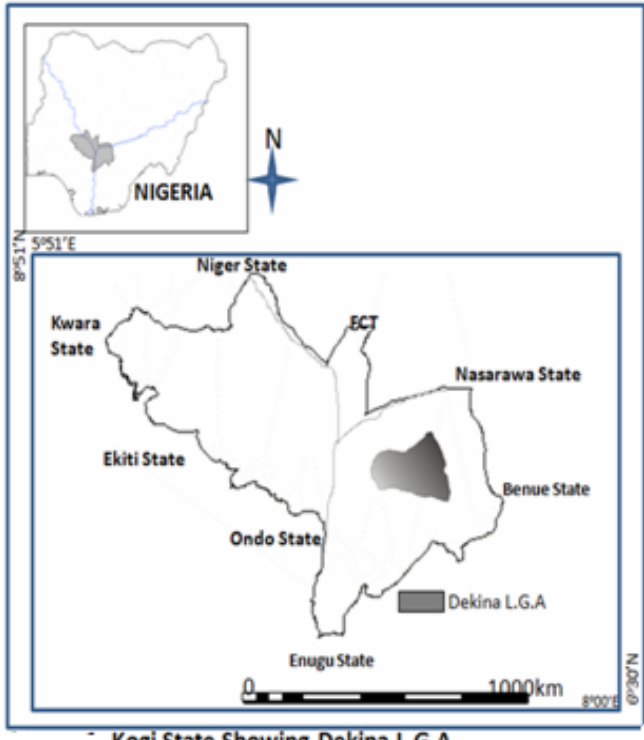

Kogi State Showing Dekina L.G.A

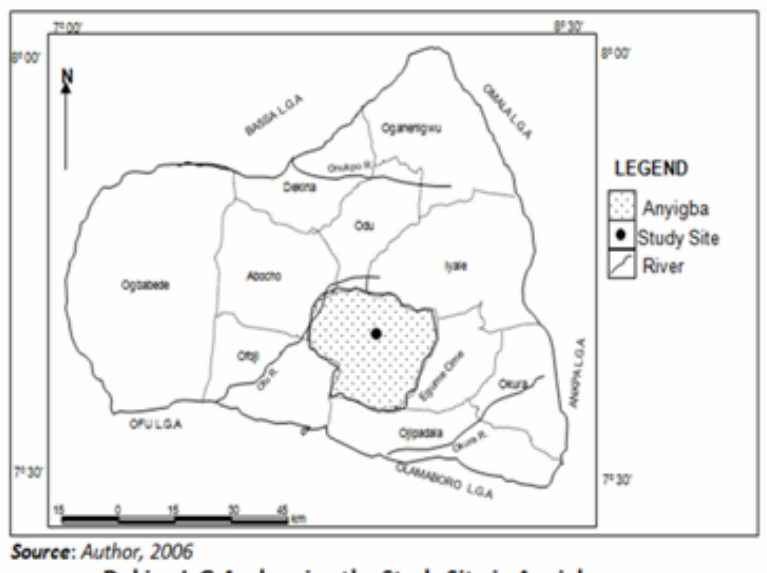

Dekina L.G.A. showing the Study Site in Anyigba

Figure 1. The study area

\section{Pre - field check}

Landsat TM and Nigeriasat 1

Field check and

\section{Post field check}

Landsat TM and Nigeriasat 1

\section{Geometric correction}

Preliminary image classification for field checks

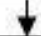

\section{Ground truth data}

Field check data

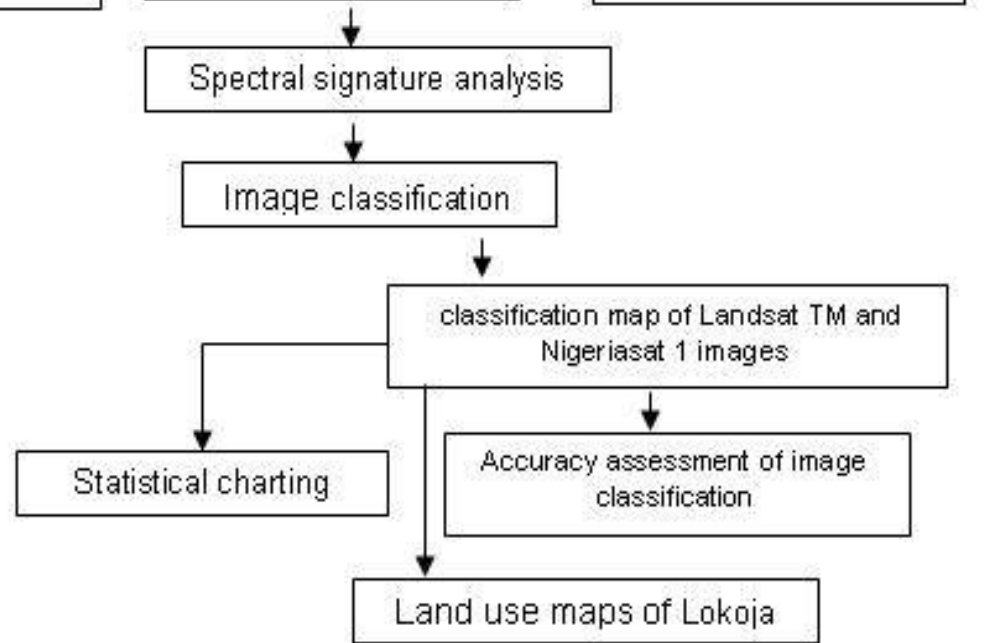

Figure 2. Methodological flowchart for Land use Classification (Source: Ifatimehin and Ufuah, 2006) 


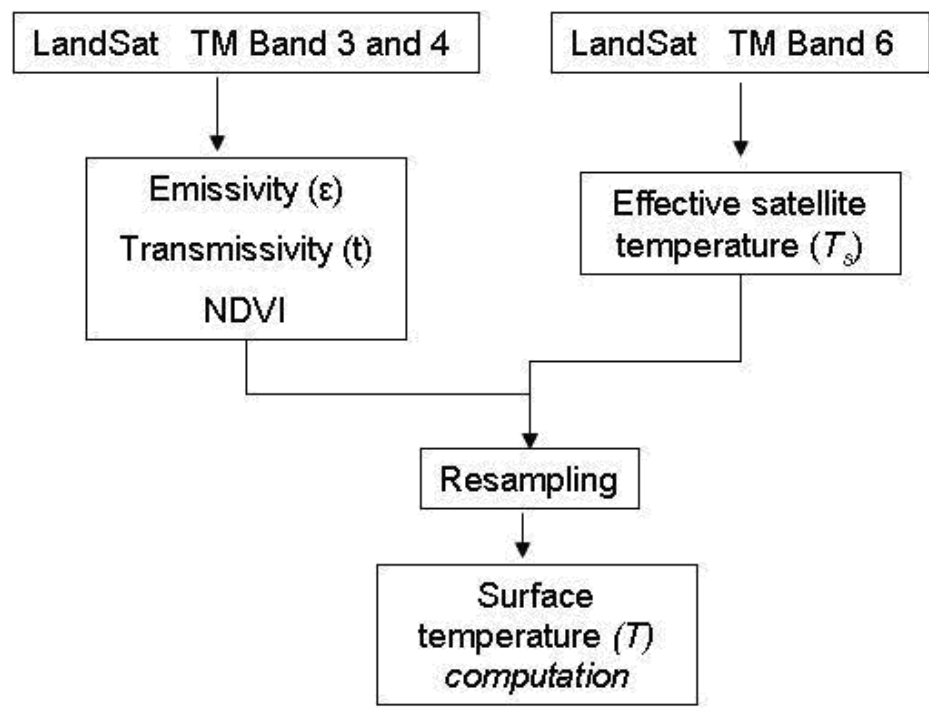

Figure 3. Flowchart for estimating surface temperature (Source: Adapted from Ifatimehin, 2007)

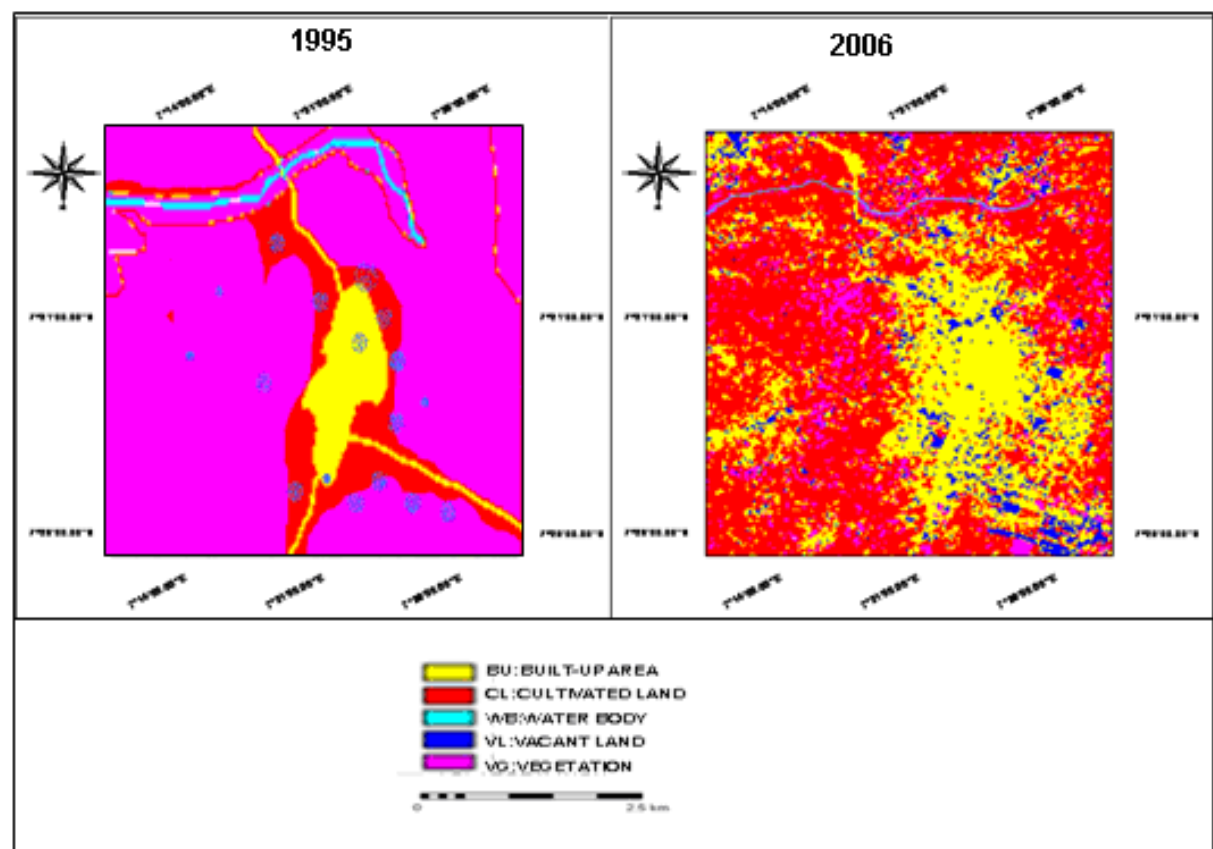

Figure 4. Classified 1995 and 2006 land use maps of Anyigba (Source: Laboratorv and Field Analysis, 2008) 


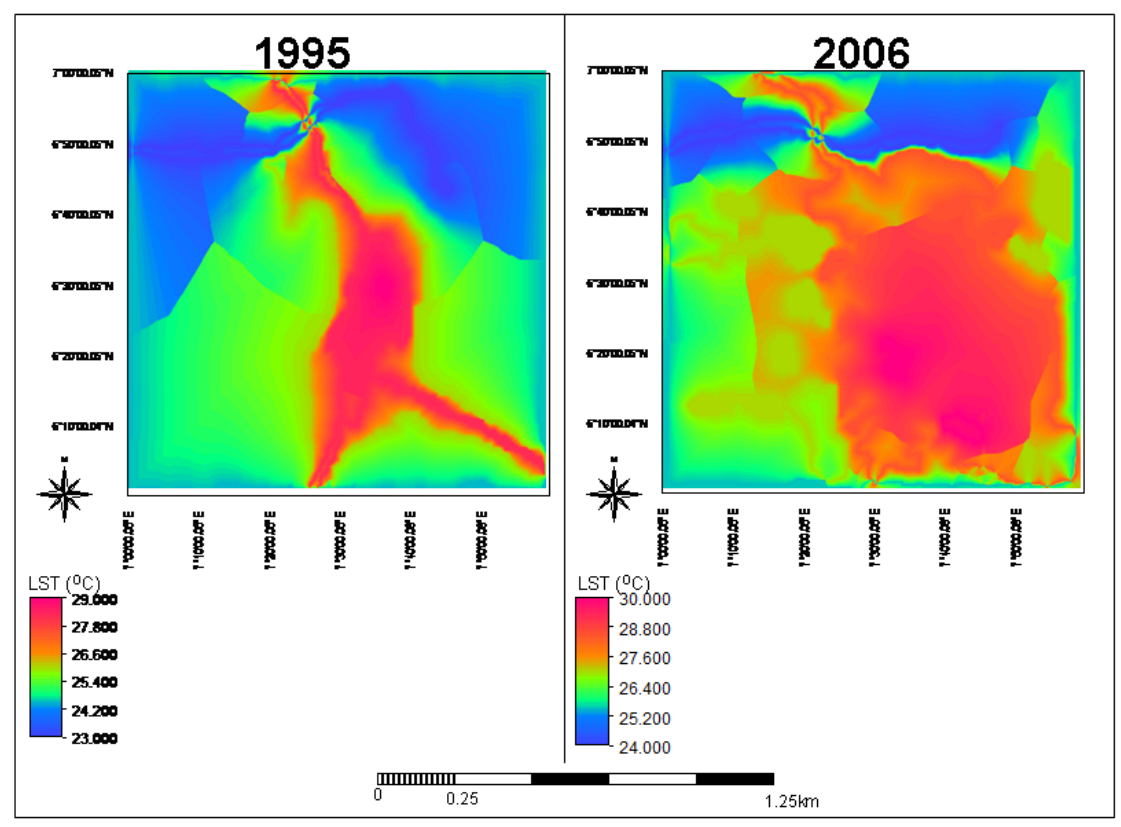

Figure 5. Classified land surface temperatures (LSTs) map of Anyigba town

(Source: Laboratory and Field Analysis, 2008) 